\title{
From Democracy to Freedom ${ }^{1}$
}

\author{
CrimethInc. ex-Workers' Collective ${ }^{2}$
}

The discourse of democracy is popular across the political spectrum. Should anarchists and other critics of hierarchal power assume that this discourse will suffice to promote self-determination and egalitarianism? We delineate the various ways that democratic rhetoric is used, review the different practices that have historically been described as democratic, and analyze what essential elements they have in common. In the field of semantics, we find that the language of democracy is too broad and too contested to be useful for distinguishing anti-authoritarian projects from projects that affirm state power and the centralization of political legitimacy; in the field of history, we find that the vast majority of democratic institutions, including experiments with "direct democracy," have reproduced the same exclusivity, coercion, and centralization that democracy is supposed to counteract; in the field of strategy, we argue that rather

\footnotetext{
${ }^{1}$ The following extract is taken from the book From Democracy to Freedom: The Difference between Government and Self-Determination, which also includes case studies of experiments with direct democracy in Barcelona during the 15M movement of 2011, the occupation of Syntagma Square in Athens in 2011, the Occupy movement throughout the United States in 2011-2012, the wave of protest in Slovenia of 2012-2013, the plenum movement in Bosnia in 2014, and the French Revolution of 1848-1851.

This text is based in the authors' combined experience in over two decades of social movements in Europe and the Americas - the Counter-Globalization Movement (including the summit protests in Seattle in 1999, Washington, DC and Philadelphia in 2000, Quebec City in 2001, Miami in 2003, Gleneagles in 2005, Heiligendamm in 2007, Pittsburgh in 2009, Toronto in 2010, and Hamburg in 2017), the movement against the invasion and occupation of Afghanistan and Iraq, Occupy Wall Street, Occupy Oakland, and other Occupy encampments around the US, the "Movement of the Squares" in Barcelona and Athens, the Slovenian uprising of 2012-2013, the free fare movement in Brazil in 2013, the plenum movement of 2014 in Bosnia, and the defense of Rojava from ISIS in 2015-2016, not to mention many other organizing initiatives, both formal and informal. The anecdotes herein that are not otherwise cited were witnessed firsthand by contributors.

${ }^{2}$ CrimethInc. (www.crimethinc.com) is a global network of participants in social movements who collaborate to produce anonymous collective reporting and analysis. Since 1995, CrimethInc. has published over a dozen books, several long-running periodicals, and hundreds of other texts. Address correspondence to: CrimethInc., e-mail: hello@crimethinc.com.
} 
than relying on the discourse of democracy, proponents of freedom, equality, and inclusivity should experiment with new frameworks and practices that promote autonomy, heterogeneity, and alternative forms of conflict resolution. [Article copies available for a fee from The Transformative Studies Institute. E-mail address: journal@transformativestudies.org Website: http://www.transformativestudies.org 02020 by The Transformative Studies Institute. All rights reserved.]

KEYWORDS: Anarchism, Democracy, Social Movements, Direct Democracy, Autonomy.

Democracy is the most universal political ideal of our day. George Bush invoked it to justify invading Iraq; Obama congratulated the rebels of Tahrir Square for bringing it to Egypt; Occupy Wall Street claimed to have distilled its pure form. From the Democratic People's Republic of North Korea to the autonomous region of Rojava, practically every government and popular movement calls itself democratic.

And when there are problems with democracy, what's the cure? Everyone agrees: more democracy. Since the turn of the century, we've seen a spate of new movements promising to deliver real democracy, in contrast to ostensibly democratic institutions that they describe as exclusive, coercive, and alienating.

Is there a common thread that links all these different kinds of democracy? Which of them is the real one? Can any of them deliver the inclusivity and freedom we associate with the word?

Impelled by our own experiences in directly democratic movements, we've returned to these questions. Our conclusion is that the dramatic imbalances in economic and political power that inspired occupations and uprisings from New York City to Sarajevo are not incidental defects in specific democracies, but structural features that date back to the origins of democracy itself; they appear in practically every example of democratic government through the ages. Representative democracy preserved all the bureaucratic apparatus that was originally invented to serve kings; direct democracy tends to recreate this on a smaller scale, even outside the formal structures of the state. Democracy and selfdetermination are two different things.

To be sure, many good things are regularly described as democratic. What follows is not an argument against discussions, collectives, assemblies, networks, federations, or working with people you don't always agree with. The argument, rather, is that when we engage in those practices, if we understand what we are doing as democracy - as a form of participatory government rather than a collective pursuit of freedom 